WORKING PAPER

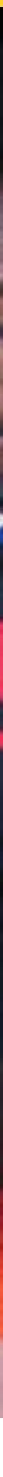

\title{
Literature review of participatory measurement, reporting and verification (PMRV)
}

Sandra Dharmadi Hawthorne

Manuel Boissière 



\section{Literature review of participatory measurement, reporting and verification (PMRV)}

Sandra Dharmadi Hawthorne

Center for International Forestry Research (CIFOR)

Manuel Boissière

Center for International Forestry Research (CIFOR)

Agricultural Research Center for International Development (CIRAD) 
Working Paper 152

(C) 2014 Center for International Forestry Research

Content in this publication is licensed under a Creative Commons Attribution-NonCommercial-NoDerivs 3.0 Unported License http://creativecommons.org/licenses/by-nc-nd/3.0/

Hawthorne SD and Boissière M. 2014. Literature review of participatory measurement, reporting and verification (PMRV). Working Paper 152. Bogor, Indonesia: CIFOR.

Cover photo by Manuel Boissière

Participatory mapping in Papua (Indonesia).

\section{CIFOR}

Jl. CIFOR, Situ Gede

Bogor Barat 16115

Indonesia

$\mathrm{T}+62(251) 8622-622$

$\mathrm{F}+62(251) 8622-100$

Ecifor@cgiar.org

\section{cifor.org}

We would like to thank all donors who supported this research through their contributions to the CGIAR Fund. For a list of Fund donors please see: https://www.cgiarfund.org/FundDonors

Any views expressed in this publication are those of the authors. They do not necessarily represent the views of CIFOR, the editors, the authors' institutions, the financial sponsors or the reviewers. 


\section{Table of contents}

Acknowledgments $\quad$ v

Executive summary

1 Introduction 1

2 Methods 3

3 MRV requirements in the REDD+ context 4

3.1 Measurement of carbon and non-carbon data 4

3.2 Reporting 5

3.3 Verification 5

3.4 Challenges in MRV implementation $\quad 5$

4 Review of the participatory approach in monitoring and MRV

4.1 Current state of knowledge $\quad 6$

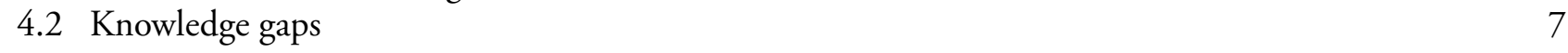

5 Developing the PMRV approach for Indonesia 9

5.1 National REDD+ and MRV in Indonesia 9

5.2 Current MRV implementation at the sub-national and local levels $\quad 13$

5.3 Opportunities and challenges in developing PMRV 15

6 Discussion and conclusion $\quad 17$

7 References $\quad 19$

Appendices

1 REDD+ demonstration activities in Indonesia 23

2 MRV strategies and implementation of REDD+ demonstration activities 26 


\section{List of figures and tables}

\section{Figures}

1 Flow of measurement and reporting in the multi-level MRV system.

2 MRV Institution collects data from various ministries, agencies and stakeholders at the national and sub-national levels.

3 The organizational structure of FREDDI.

4 The structure and development modules of the proposed District Forest Management Information System (DFMIS).

\section{Tables}

1 Summary of the tier system and its requirements for data and methods to estimate emission factors (IPCC 2006; GOFC-GOLD 2012)

2 Examples of research projects that have implemented participatory measurement of carbon stocks in Indonesia 


\section{Acknowledgments}

The authors would like to thank the following people for sharing their knowledge of the MRV system and its implementation in Indonesia: Agus Setyarso (IGES), M. Rayan (GIZ), Ari Wibowo (FORDA), Grahame Applegate (KFCP), Didiek Surjanto (WWF), Arief Darmawan (Satuan Tugas REDD+ MRV), Philippe Guizol (CIRAD and Agence Française pour le Développement), Shijo Joseph (CIFOR), Daju Resosudarmo (CIFOR), William Sunderlin (CIFOR), Stibniati Atmadja (CIFOR). We are also grateful to Daniel Mudiyarso and Christopher Martius for reviewing the early version of the manuscript, and Glen Mulcahy for editing the final manuscript. This study is part of the 'Participatory MRV: addressing the scale' project, funded by the U.S. Agency for International Development (USAID) and Norwegian Agency for Development (NORAD). This research was carried out by the Center for International Forestry Research (CIFOR) and the Centre de coopération Internationale en Recherche Agronomique pour le Développement (CIRAD), as part of the CGIAR Research Program on Forests, Trees and Agroforestry, and in collaboration with the University of Gadjah Mada (UGM). 


\section{Executive summary}

Measurement, reporting and verification (MRV)

of carbon stocks are crucial components of Reducing Emissions from Deforestation and Forest Degradation and the role of conservation, sustainable management and the enhancement of forest carbon stocks (REDD+). The application of a participatory approach in MRV aims to collect local carbon stock data to improve the accounting of greenhouse gas (GHG) emissions at the national level and increase the participation of local communities to maximize the co-benefits of REDD+. The design and implementation of participatory MRV (PMRV) may benefit from extensive research and application of participatory monitoring of natural resources and biodiversity. However, participatory monitoring and PMRV have different aims and requirements. The strategies that contribute to successful participatory monitoring may need to be modified and adapted to the requirements of MRV to be useful for PMRV.

We conducted a literature review of participatory monitoring and existing PMRV approaches to identify strategies and conditions that support the development and implementation of sustainable PMRV in the REDD+ context. To identify data and processes that should be included in PMRV, we reviewed MRV requirements in the REDD+ context. The literature is analyzed to summarize the lessons learned from participatory monitoring, examine when, where and how PMRV has been developed and implemented, and identify any knowledge gaps. With Indonesia as our case study, we explored the feasibility of PMRV implementation and assessed how PMRV could be integrated into the national MRV system. We examined the proposed national
MRV system in Indonesia, compiled a database of REDD+ projects and conducted short interviews with selected project proponents.

We have identified several knowledge gaps in the current literature on participatory monitoring and PMRV, such as the impact of MRV requirements on the feasibility and sustainability of PMRV, limited literature on participatory reporting and validation processes, the integration of PMRV into the multi-level MRV system and how PMRV can be used to ensure REDD+ safeguards and to maximize co-benefits. Our examination of the development of the multi-level MRV system and MRV implementation in Indonesia have shown the opportunities and challenges in integrating PMRV into the MRV system and implementing PMRV at the local level.

We recommend that PMRV, for carbon and noncarbon data, be developed and implemented in community-based forest management schemes. The potential of PMRV to maximize the co-benefits of REDD+ and implement REDD+ safeguards should be promoted and realized to encourage the adoption of PMRV by REDD+ project proponents at the local level. Robust participatory reporting methods and reliable validation need to be identified. PMRV activities should be carried out as a partnership between the local communities, local institutions, government agencies at the district level, the MRV unit at the provincial level and its counterpart at the national level. This will enable PMRV to be well supported and the collected data aggregated at the national level. 


\section{Introduction}

Deforestation and degradation of tropical forests produce approximately $8-10 \%$ of global greenhouse gas (GHG) emissions (Baccini et al. 2012; Harris et al. 2012). Reducing Emissions from Deforestation and forest Degradation plus (REDD+) was launched as a climate mitigation strategy at the 13th session of the Conference of the Parties (COP13) of the United Nations Framework Convention on Climate Change (UNFCCC) in Bali, in December 2007. It is a performance-based scheme that provides incentives for developing countries to reduce their GHG emissions through reducing deforestation and degradation of forest cover, conserving forest carbon stocks, sustainable forest management and enhancement of carbon stocks. It has the potential to contribute to climate change mitigation rapidly with relatively low cost, improve the livelihoods of local indigenous and rural communities, conserve forest biodiversity and enhance forest ecosystem services.

The measurement, reporting and verification (MRV) of carbon stocks are crucial in assessing the effectiveness of the REDD+ scheme and the financial incentives associated with emission reduction. To ensure that emission reduction is permanent and additional (Angelsen et al. 2008), the MRV system is required to estimate carbon emissions at the national level, while assessing the effectiveness of REDD+ demonstration activities (projects) and improving the accuracy of the GHG accounting at the sub-national level (Herold and Skutsch 2009). Thus, the MRV system needs to integrate and manage data across geographical scales and multiple government levels (Korhonen-Kurki et al. 2012).

The concept of a participatory approach in MRV (PMRV) is attractive because it has the potential to provide cost-effective and locally collected biomass data, promote equality in benefit sharing and maximize the social and environmental co-benefits of REDD+ (Graham and Thorpe 2009; Skutsch et al. 2009; Danielsen et al. 2011; Fry 2011; Mukama et al. 2012; Danielsen et al. 2013; Pratihast et al. 2013). The development of PMRV has been prompted by extensive research and practical experiences gained from participatory monitoring, for biodiversity conservation and natural resource management, by forest-dependent communities (Danielsen et al. 2005a; Evans and Guariguata 2008). Participatory monitoring can be described as the involvement of local people, who may have varying skills, expertise, societal roles and interests in monitoring activities (Evans and Guariguata 2008). The degree of local community participation can vary from paid or unpaid labor for data collection to initiating and conducting the whole monitoring process for their own purpose (Danielsen et al. 2009).

As no formal definition of PMRV exists, we propose that PMRV be defined as the involvement of local people in the measurement, reporting and verification of carbon stocks and other data (e.g. biodiversity, ecosystem services, drivers of deforestation or degradation) that are required to assess the impact and co-benefits of REDD+. Participatory reporting requires the integration of local carbon stock data into a national monitoring system, such as a national forest inventory or other types of database. Verification of the collected and reported data from PMRV should be carried out by an independent, extra-national organization (GOFC-GOLD 2012). In the case that remote sensing data have been used to estimate carbon stocks and emission reduction at the national level, the locally collected data can be used to validate those data (Skutsch et al. 2009). Our definition of PMRV encompasses different degrees of participation to enable the best PMRV approach to be developed.

Some of the lessons learned from participatory monitoring, such as the strategies to build local capacity or sustain long-term monitoring (Danielsen et al. 2005a; Evans and Guariguata 2008), may be useful for developing a PMRV approach. However, the requirements and implementation scale of PMRV can differ from participatory monitoring. The objectives and methods for participatory monitoring (what and how to monitor) can be developed collaboratively with the local communities and other stakeholders (Danielsen et al. 2005a; StuartHill et al. 2006; Evans and Guariguata 2008), while MRV requirements for carbon stocks are based 
on international requirements that are prescribed in IPPC Good Practice Guidelines (IPCC 2006; GOFC-GOLD 2012). An important benefit of participatory monitoring, which is also a strong incentive for monitoring, is the use of monitoring results to inform local management decisions (Danielsen et al. 2005a; Evans and Guariguata 2008; Danielsen et al. 2009). Meanwhile, the benefits of PMRV for local communities may be limited unless PMRV is applied in community-managed forests and/or financial incentives are linked to MRV activities (Skutsch et al. 2009; Danielsen et al. 2011). These differences raise several research questions, such as which lessons from participatory monitoring can be used to develop a sustainable PMRV in the REDD+ context and what conditions are required for its implementation.
This literature review identifies strategies and conditions that support sustainable PMRV in the REDD+ context using Indonesia as a case study. The next chapter outlines the methods used in this literature review. Chapter 3 describes the requirements of an MRV system in the REDD+ context and discusses the challenges in its implementation. Chapter 4 reviews the recent literature on participatory approaches in natural resource monitoring and MRV, and identifies the knowledge gaps in the literature. Chapter 5 explores the proposed and existing MRV frameworks in Indonesia and discusses the development of the PMRV approach that may be appropriate for the Indonesian context. The last chapter discusses the implications of the findings and presents the conclusion. 


\section{Methods}

The requirements, development and implementation of the MRV system in the REDD+ context were reviewed to provide the context for assessing the suitability of the PMRV approach. They were obtained from various IPCC guidelines on MRV (IPCC 2003; IPCC 2006) and published literature on the development of REDD+ (Angelsen et al. 2009; Angelsen et al. 2012). The challenges in the establishment of a credible MRV system were also identified.

For the literature search, we used the Web of Knowledge database, the Google search engine and the Center for International Forestry Research (CIFOR) publications. The Google search led to the discovery of various online resources on REDD+ publications, country and project profiles, such as the REDD Desk (www.theredddesk.org), the Institute for Global Environmental Strategies (IGES) and the REDD+ Database (http://redd-database.iges. or.jp/redd/). EndNote (Thomson Reuters, USA) was used to organize and record the citations of the peer-reviewed and gray literature found during the literature search. The peer-reviewed and gray literature was analyzed to assess the costs and benefits of a participatory approach, and identify strategies for sustainable PMRV and knowledge gaps.
The next step was to examine the existing MRV framework and practices in Indonesia. The National MRV Strategy and Implementation document was used to assess the national MRV framework (REDD+ Task Force 2013). A database of REDD+ demonstration activities (DAs) in Indonesia (see Appendix 1) was compiled based on information from the REDD Desk, IGES REDD+ database, REDD Indonesia (http://www.redd-indonesia.org/), UN-REDD Programme for Indonesia (Mardiastuti 2012a) and CIFOR's Global Comparative Study on REDD+ (http://www.cifor.org/gcs/about-gcs/ redd-project-sites/redd-project-sites-in-indonesia. $\mathrm{html}$ ). The MRV strategies and implementation at the DA level were obtained from project design documents that are publicly available, as well as from short interviews with three project proponents (see Appendix 2). Each interview was conducted face-to-face with open questions about how MRV activities were implemented, the involvement (if any) of the local communities in the activities and benefits, and barriers to involvement. The collected information was used to assess the opportunities and challenges in Indonesia in developing PMRV approaches at the local/sub-national level. 


\section{MRV requirements in the REDD+ context}

\subsection{Measurement of carbon and non-carbon data}

Forest carbon emissions are calculated by combining the change in forest area and emission factors (IPCC 2006; GOFC-GOLD 2012). The change in forest area (ha) can be estimated from a wall-to-wall mapping or sampling of remote sensing data. Forest degradation generally results in small changes in canopy cover so the areal extent of degradation is more difficult to detect with optical remote sensing than the areal extent of deforestation (DeFries et al. 2007). Airborne laser altimetry (such as light detection and ranging LiDAR) produces promising results for monitoring degradation (Asner et al. 2010), but some groundbased carbon inventory may still be required to estimate and monitor forest degradation.

Emission factors are derived from the changes in carbon stocks per unit area $\left(\mathrm{t} \mathrm{C} \mathrm{ha}^{-1}\right)$ under different land use changes. The changes in carbon stocks must be estimated in five carbon pools: aboveground biomass, belowground biomass, dead wood, litter and soil organic matter (GOFCGOLD 2012). Above- and belowground carbon stocks are generally estimated using an allometric equation that is developed from the measurements of local biomass for a specific area or forest type. To calculate carbon stocks in dead wood, samples of dead wood are usually collected along a transect and dried to calculate their density. Litter is generally collected with trays over a period of time, removed, dried and weighed. Soil carbon stocks require a laboratory analysis of soil samples to estimate the bulk density and percent of soil carbon, which can be costly. New approaches using near-infrared scanning technology to reduce the need of lab analysis are underway but require the establishment of calibration models and these are not yet widely available. Two methods can be used to estimate the change in carbon stocks: gain-loss and stock-difference (GOFC-GOLD 2012). The gain-loss method estimates the net balance of gain (vegetation growth) and loss (wood removal and disturbance) of carbon stocks. The stock-difference method estimates the difference in carbon stocks at two moments in time in a carbon pool.

The data and methods used to estimate the change in carbon stocks are categorized into three tiers, with increasing levels of data requirement and accuracy (Table 1). The changes in carbon stocks of significant pools should be estimated using a higher tier to reduce uncertainty and increase accuracy. To obtain REDD+ incentives, Tier 3 data and methods are likely to be required in the estimation of carbon stocks. Thus, significant efforts in readiness activities have been dedicated to increase the capability of nonAnnex I countries to collect and analyze Tier 3 data.

Table 1. Summary of the tier system and its requirements for data and methods to estimate emission factors (IPCC 2006; GOFC-GOLD 2012)

\begin{tabular}{llll}
\hline & Tier 1 & Tier 2 & Tier 3 \\
\hline Emission factors & IPCC default factors & Country-specific factors & $\begin{array}{l}\text { Estimated from forest } \\
\text { carbon inventory and/or a } \\
\text { calibrated process model }\end{array}$ \\
\hline $\begin{array}{l}\text { Spatial and temporal } \\
\text { resolution of data }\end{array}$ & Low & Medium & High \\
\hline $\begin{array}{l}\text { Estimation of net emissions } \\
\text { from deforestation }\end{array}$ & $\begin{array}{l}\text { Assumed to be } \\
\text { instantaneous }\end{array}$ & $\begin{array}{l}\text { Assumed to be } \\
\text { instantaneous }\end{array}$ & $\begin{array}{l}\text { Modeled transfer of carbon } \\
\text { stocks between pools over } \\
\text { time }\end{array}$ \\
\hline $\begin{array}{l}\text { Estimation of net emissions } \\
\text { from degradation }\end{array}$ & Gain-loss method & Gain-loss or & Stock-difference method \\
\hline
\end{tabular}


The implementation of REDD+ safeguards requires the measurement or collection of non-carbon data, such as livelihoods, ecosystem functions or biodiversity. However, the types of data or the collection methods have not been prescribed in detail.

\subsection{Reporting}

Forest carbon emissions must be reported in the national anthropogenic GHG inventory, which is submitted to UNFCCC. Detailed reporting guidelines for annual GHG inventories have been set out in the 2006 IPCC Guidelines on Agriculture, Forestry and Other Land Use (IPCC 2006) for Annex I countries. The general principles for estimating and reporting GHG emissions and removals are transparency, consistency, comparability, completeness and accuracy. The same guidelines and principles are likely to be used for non-Annex I countries that participate in REDD+, although they are not required to produce an annual GHG inventory immediately.

Although the estimation and reporting of forest carbon emissions are conducted at the national level, the changes in carbon stocks are likely to be reported at multiple levels. The proponents of REDD+ activities at local and sub-national levels need to report changes in carbon stocks to an MRV institution at the next governance level and potentially to other institutions or agencies (e.g. funding agencies). The estimation of national carbon emissions may also rely on the national forest inventory (Tier 3), which systematically and regularly collects in situ carbon stock data across the country. Thus, a consistent reporting procedure for carbon stock data is required within the multi-level MRV system.

\subsection{Verification}

Verification is a collection of activities or procedures to establish the reliability and accuracy of the GHG inventory (IPCC 2003). It can be performed at project, sub-national, national and international levels. It may involve the comparison of inventory estimates against estimates that are independently derived, or the examination of data quality, assumptions and methods used in analysis, and upscaling procedures. The 2003 Good Practice Guidelines for Land Use, Land-Use Change and Forestry (GPG-LULUCF) recommends five approaches that can be used to perform verification of the inventory estimates (IPCC 2003):

- comparison against other information, such as independent inventories or international datasets

- application of higher tier methods

- direct measurement of GHG emissions and removals

- remote sensing

- application of a process model.

Internal verification can be performed by the agency responsible for the national GHG inventory, while external verification is performed by an independent organization (third party).

\subsection{Challenges in MRV implementation}

A credible national MRV system requires forest monitoring and inventory data, as well as the institutional capacity to produce and report GHG inventory estimates of the LULUCF sector. The system also needs to integrate data across a range of scales and levels. However, medium to large capacity gaps in establishing a national forest monitoring system for MRV have been identified in most tropical non-Annex I countries (Herold and Skutsch 2009; Romijn et al. 2012). They are mostly due to a lack of data (especially carbon stock measurements); limited capacity to collect, manage and analyze data; and limited access to technology and resources (Romijn et al. 2012).

A comprehensive MRV system that monitors social impacts of REDD+ on the local communities (i.e. livelihoods, environmental awareness, empowerment), ecosystem responses and biodiversity will ensure REDD+ safeguards are implemented and enable the co-benefits of REDD+ to be assessed. However, this may place an additional burden on the development of such a system. If these attributes are included in the design of multi-level MRV, the overall cost of data collection might be lower than collecting and managing the carbon stocks and REDD+ safeguards separately (outside MRV). 


\section{Review of the participatory approach in monitoring and MRV}

This chapter reviews the literature on participatory monitoring of forest resources and biodiversity, and the literature on PMRV in the REDD+ context. The first section in this chapter presents the current state of knowledge on participatory monitoring and PMRV. The second section identifies knowledge gaps in the literature.

\subsection{Current state of knowledge}

\subsubsection{Participatory monitoring}

Participatory monitoring of forest resources and biodiversity by local communities can deliver multiple benefits, such as:

- build social capital and empower local people (Hartanto et al. 2002; Danielsen et al. 2005a; Constantino et al. 2012)

- improve livelihoods (Klooster and Masera 2000; Chhatre and Agrawal 2009)

- reduce forest degradation (Klooster and Masera 2000; Chhatre and Agrawal 2009; Porter-Bolland et al. 2012)

- conserve biodiversity (Klooster and Masera 2000; Sheil and Lawrence 2004; Lawrence et al. 2006)

- inform decision making at the local level and facilitate adaptive management (Danielsen et al. 2005a; Danielsen et al. 2005b; Poulsen and Luanglath 2005; Topp-Jorgensen et al. 2005; Stuart-Hill et al. 2006)

- provide data for national/international monitoring systems (Danielsen et al. 2005a; Poulsen and Luanglath 2005; Topp-Jorgensen et al. 2005; Stuart-Hill et al. 2006).

Participatory monitoring is more suited to implementation in community-managed forests compared with protected forests due to the clear link between monitoring and management that will benefit the local communities (Klooster and Masera 2000; Garcia and Lescuyer 2008). Financial, social and personal incentives are also important to motivate individual involvement in participatory monitoring (Poulsen and Luanglath 2005; ToppJorgensen et al. 2005).
The challenges in participatory monitoring include sustaining the program over the long term, insufficient cost-benefit analysis, developing simple and scientifically robust methods and scaling up monitoring programs (Evans and Guariguata 2008; Garcia and Lescuyer 2008). To ensure sustainability, a participatory monitoring program should be simple to conduct, cost effective (i.e. benefits outweigh opportunity costs), locally relevant and built on existing management or traditional institutions (Danielsen et al. 2005a; Evans and Guariguata 2008). There are some trade-offs between managementoriented, locally relevant monitoring and larger scale, scientifically oriented monitoring (Stuart-Hill et al. 2006; Garcia and Lescuyer 2008). Thus, a compromise is needed to ensure that a monitoring program yields meaningful information for local stakeholders and captures environmental changes on a large scale.

Several studies have demonstrated the integration of local data from participatory biodiversity monitoring into the national monitoring system (Danielsen et al. 2005b; Stuart-Hill et al. 2006). They found that the local monitoring program needed to be nested in a larger monitoring framework that is supported and facilitated by government agencies at various levels. In other studies, the failure to integrate locally collected data into a larger scale monitoring system has been attributed to a lack of support or capacity of the local government agency in reporting and data analysis (Hartanto et al. 2002; Poulsen and Luanglath 2005; Topp-Jorgensen et al. 2005).

\subsubsection{Participatory measurement, reporting and verification (PMRV)}

The potential reduction in the long-term cost of obtaining local (Tier 3) carbon data has been an important incentive for implementing PMRV, as well as promoting equality in benefit sharing and maximizing the social and environmental co-benefits of REDD+ (Graham and Thorpe 2009; Skutsch et al. 2009; Danielsen et al. 2011; Fry 2011; Mukama et al. 2012; Danielsen et al. 2013; Pratihast et al. 2013). Participatory measurement for carbon stocks has been developed and implemented to assess the 
ability of local communities to measure carbon stocks and the costs (Skutsch et al. 2009; Danielsen et al. 2011; Mukama et al. 2012; Danielsen et al. 2013). These studies were mostly conducted in community-managed forests (Skutsch et al. 2009; Danielsen et al. 2011; Mukama et al. 2012; Danielsen et al. 2013), with a few being conducted in state-owned forests (Danielsen et al. 2013). The results are described in the following sub-sections.

Accuracy comparison. Skutsch et al. (2009) find that the difference in the estimated mean biomass obtained from professional surveys and participatory (community) measurements was often less than 5\% in the Kyoto: Think Global, Act Local studies, while the variance of estimates was higher for some of the data collected by the local communities. A study by Danielsen et al. (2011) finds that there was no significant difference in the estimates of mean aboveground biomass between professional and community-based measurements, while another study by Danielsen et al. (2013) shows that there was a significant difference in onethird of the study sites. A lack of technical expertise or a conflict of interest have been identified as the potential sources of bias in the measurements (Danielsen et al. 2005a). The following strategies can increase the accuracy of the local communities' measurements (Danielsen et al. 2005a; Skutsch et al. 2009; Danielsen et al. 2013):

- Increase the number of plots sampled by onethird or double.

- Use robust sampling and measurement methods.

- Increase training.

Cost comparison. The cost of participatory measurements included training, supervision, minimum wages and equipment, while the cost of the professional survey included travel, accommodation, wages and equipment. Skutsch et al. (2009) find that the average cost of participatory measurements over four years was about onequarter of the cost of a professional survey. They suggested that PMRV activities by the local communities should be funded from the carbon credit received under Payment for Environmental Services (PES) or REDD+ schemes. Danielsen et al. $(2011,2013)$ find the average cost of participatory measurements over four years varied between onethird to equal the cost of a professional survey.
Training is the largest component in the total cost of participatory measurements, which can vary between $24 \%$ to $42 \%$ of the total projected cost over four years (Danielsen et al. 2013). Mukama et al. (2012) show that increasing the cost of participatory measurements to better reflect the opportunity costs, instead of applying the minimum wage, could still make the total cost lower than a professional survey.

In a REDD+ project in Cambodia, Brewster et al. (2011) find that continually changing participants in the measurement teams prevented the development of important skills, while varying levels of motivation and work ethics affected the precision of measurements. Limited availability of local staff from the Forest Administration to assist with the biomass measurements also had a negative effect. They also discovered that the local communities, conducting biodiversity monitoring, required further training in the identification of mammal species, and some community members were prevented from being actively involved because of a conflict of interest.

\subsection{Knowledge gaps}

We have identified some knowledge gaps from the literature that may affect the development and implementation of PMRV.

\subsubsection{Impact of MRV requirements on the feasibility and sustainability of PMRV}

Most PMRV studies have discussed the potential benefits of PMRV (lower MRV costs, empowerment and engagement of indigenous communities and more transparent benefit sharing), but they have not discussed the constraints that MRV requirements may have on the feasibility and sustainability of PMRV. The proportion of training costs to the total projected costs over four years was substantial (up to $42 \%$ ), which reflects the relative complexity of the tasks required for a biomass inventory. This means that participatory measurements are more cost effective than a professional survey if repeated measurements are required over the long term. Lessons from participatory monitoring have shown that locally relevant monitoring objectives and the link between monitoring results and management decisions (Danielsen et al. 2005a; Evans and Guariguata 2008; Danielsen et al. 2011) are important for its sustainability. Unless PMRV is conducted in community-managed forests, 
these conditions will not be met. Meanwhile, only a small proportion (on average $<15 \%$ ) of forest in developing countries is formally under community-based management (Murdiyarso and Skutsch 2006; Chhatre and Agrawal 2009; Burgess et al. 2010), albeit to a varying extent. Increasing the participation of local communities in forest management will provide more opportunities for the PMRV approach to be implemented. Potential incentives for PMRV that will enable its implementation under other types of forest management, such as protected areas, should also be examined further.

\subsubsection{Limited literature on participatory reporting and validation processes.}

Several studies on PMRV have acknowledged the requirements for a reporting protocol and data quality control to integrate local data into the national monitoring system (Graham and Thorpe 2009; Skutsch et al. 2009; Burgess et al. 2010; Danielsen et al. 2011; Fry 2011; Danielsen et al. 2013; Pratihast et al. 2013), but they did not elaborate on the best method for reporting the collected data. The recent focus on local communities' capacity development rather than on reporting may be due to the fact that the national monitoring framework is not yet configured or fully functional in most REDD+ participating countries (Romijn et al. 2012). Validation of the locally collected data can be through random data checks, statistical analysis or comparison with high-resolution remote sensing data, which should be performed by the reporting agency or an independent party (Skutsch et al. 2009; Burgess et al. 2010; Danielsen et al. 2011). Further analysis on the best reporting framework and validation process, for the flow of monitoring data across multiple levels (local to national), is needed.

\subsubsection{Integration of PMRV as part of a multi- level MRV system.}

PMRV has been acknowledged as a feasible option for the MRV system at the national level in several REDD+ participating countries (Graham and Thorpe 2009; Burgess et al. 2010; Brewster et al. 2011, 2013). However, Danielsen et al. (2013) find that only $52 \%$ of Climate, Community and Biodiversity Alliance (CCBA)-validated projects have plans to implement varying levels of PMRV. The implementation of PMRV for carbon stocks and biodiversity in the Oddar Meanchey Community Forest REDD+ Project has shown some of the challenges experienced at the local level, such as limited availability of participants, variable levels of skills and motivation, and potential conflicts of interest. More research on PMRV implementation at the local level is required to determine the most robust and sustainable PMRV model, while the design and implementation of the national MRV system should be further examined.

\subsubsection{PMRV for REDD+ safeguards and co- benefits.}

The participatory approach in biodiversity monitoring has been shown to have positive impacts on social empowerment and biodiversity conservation (Hartanto et al. 2002; Lawrence et al. 2006; Constantino et al. 2012), but the impact of PMRV on REDD+ safeguards and co-benefits has yet to be assessed. The implementation of PMRV to obtain non-carbon data, such as the monitoring of biodiversity in the Oddar Meanchey Community Forest (Brewster et al. 2011), is currently still limited. It is unclear how data on changes in livelihoods and biodiversity will be used to assess whether REDD+ safeguards have been properly implemented or REDD+ co-benefits have been maximized. 


\section{Developing the PMRV approach for Indonesia}

Indonesia has committed to decrease its GHG emissions by $26 \%$ from the 'business as usual' development scenario by 2020 through self-funding alone, or by $41 \%$ if international assistance is provided. This commitment and Indonesia's early participation in the REDD+ scheme have enabled REDD+ implementation to progress and reach its readiness phase. We examined the (proposed) multi-level MRV system in Indonesia and MRV implementation at the project level to explore how PMRV can be integrated into the MRV system. This examination looks at the knowledge gaps in participatory reporting and integration of PMRV into a multi-level MRV system, which may make it easier for the adoption of PMRV by the national MRV systems in REDD+ participating countries. Based on the findings, the opportunities and challenges in developing PMRV are presented at the end of this chapter.

\subsection{National REDD+ and MRV in Indonesia}

The development of REDD+ institutions and strategies in Indonesia has evolved during the course of this study. A brief history of this development is presented in this section. We describe the roles and responsibilities of various REDD+ institutions, the framework for a multi-level MRV system and the flow of information between institutions that are outlined in the national REDD+ strategies and the national MRV implementation strategies. We compare the national REDD+ and MRV strategies with the later establishment of REDD+ Agency and Fund for REDD+ Indonesia (FREDDI).

The national REDD+ Task Force was created in September 2010 to oversee the establishment of a national REDD+ agency and deliver a REDD+ national strategy. The REDD+ Task Force published the REDD+ national strategy in June 2012 (REDD+ Task Force 2012) and the MRV strategy and implementation plan in June 2013 (REDD+ Task Force 2013). The national REDD+ Agency was established on 2 September 2013 through a presidential decree, which was followed by the establishment of FREDDI in late 2013.

\subsubsection{REDD+ and MRV national strategies}

The national strategy proposed the establishment of three REDD+ institutions to manage the national implementation of REDD+ (REDD+ Task Force 2012) with the following functions:

- REDD+ Agency: will coordinate, support and monitor REDD+ policies, planning and implementation.

- Funding Instrument: will establish and manage a funding mechanism for fair distribution of REDD+ benefits and incentives.

- MRV Institution: will coordinate MRV activities at different levels and compile the national GHG inventory for forests and peat swamp forests.

As per the strategy, the REDD+ Agency will set out the policies, strategies and regulations for the Funding Instrument and the MRV Institution and will report directly to the President. The MRV Institution will provide the Funding Instrument with verified results of emission reduction, while the two institutions will jointly develop protocols to evaluate REDD+ safeguards. REDD+ institutions will also be created at the sub-national levels to coordinate and implement a regional REDD+ strategy and action plan at the provincial level and/or REDD+ activities at the district level. For example: the regional REDD+ Task Force in the pilot province of Central Kalimantan has formulated REDD+ strategies at the provincial level, which could evolve into a regional REDD+ institution.

The MRV strategy and implementation plan published by the REDD+ Task Force stated that the MRV system will consist of (REDD+ Task Force 2013):

- measurement and monitoring of GHG emissions from forests and peat swamp forests at various levels

- an information system of REDD+ safeguards, co-benefits and drivers of deforestation and forest degradation. 
The responsibility to measure and report net GHG emissions will be allocated to the proponents of REDD+ activities and the national MRV Institution (Figure 1). The proponents of REDD+ activities may include provincial and/or district government, non-government organizations or civil societies, private entities and community groups that implement these activities. They will also be responsible for establishing, monitoring and reporting REDD+ safeguards, co-benefits and drivers of deforestation and forest degradation. The sub-national MRV working units at the provincial level will conduct (or collect from REDD+ proponents) more detailed measurements of carbon stocks, report the measurements to the national MRV Institution and solve administrative boundary issues related to leakage.
The proposed national MRV Institution will collect measurements and monitoring data from various government ministries and agencies, and other stakeholders (Figure 2). The stock-difference method will be used to calculate emissions and removal of GHG. The change in land cover and use will be monitored using wall-to-wall remote sensing data. National emission factors for a range of ecosystems will be developed based on carbon stock data from the permanent sample plots, which have been established as part of the National Forest Inventory (NFI) and production forest monitoring. Some of the anticipated challenges in developing the national MRV system include the difficulty in setting up protocols and standards for data collection and processing (e.g. spatial data), obtaining continuous and up-to-date data, coordination and cooperation

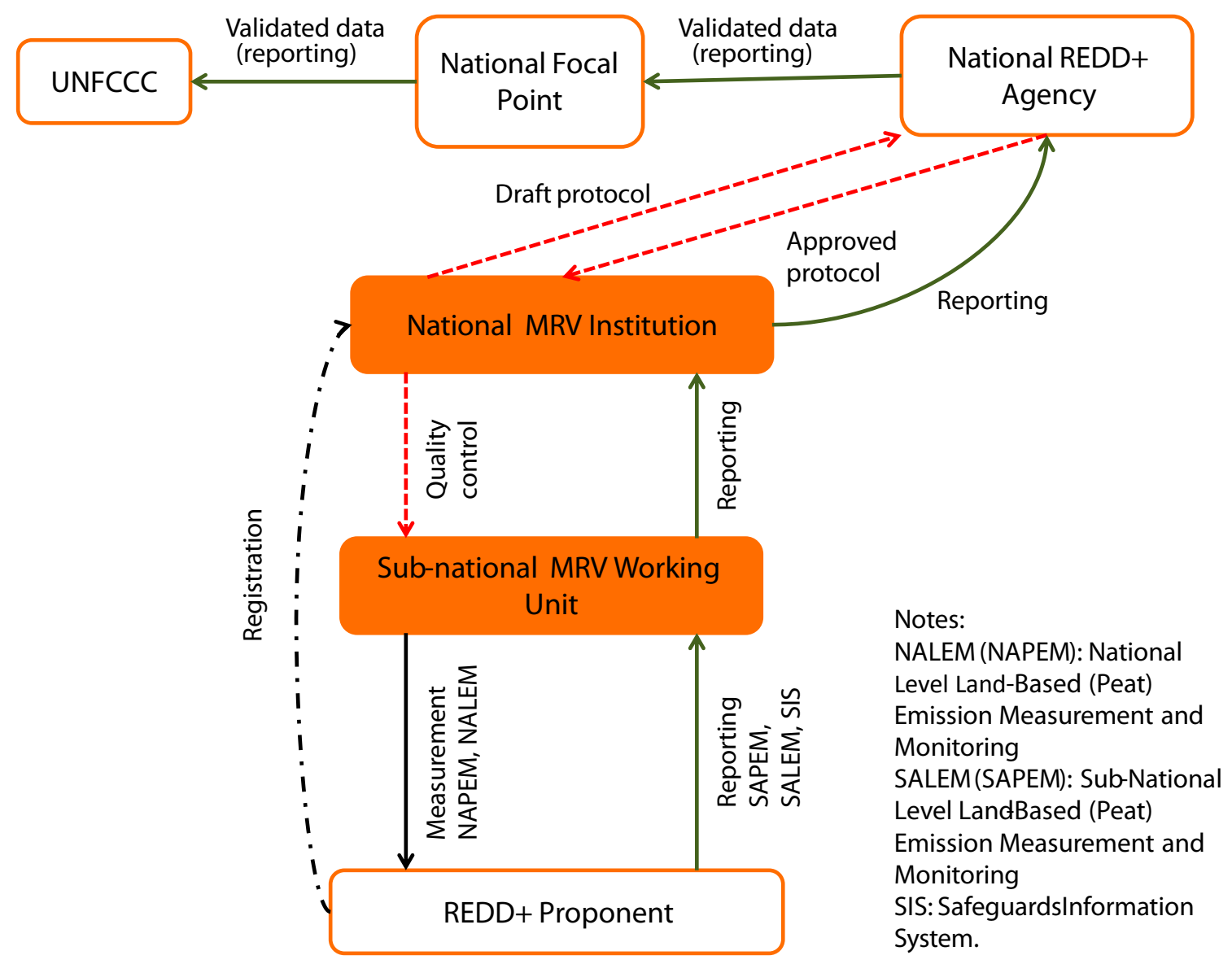

Figure 1. Flow of measurement and reporting in the multi-level MRV system.

Source: REDD+ Task Force (2013). 


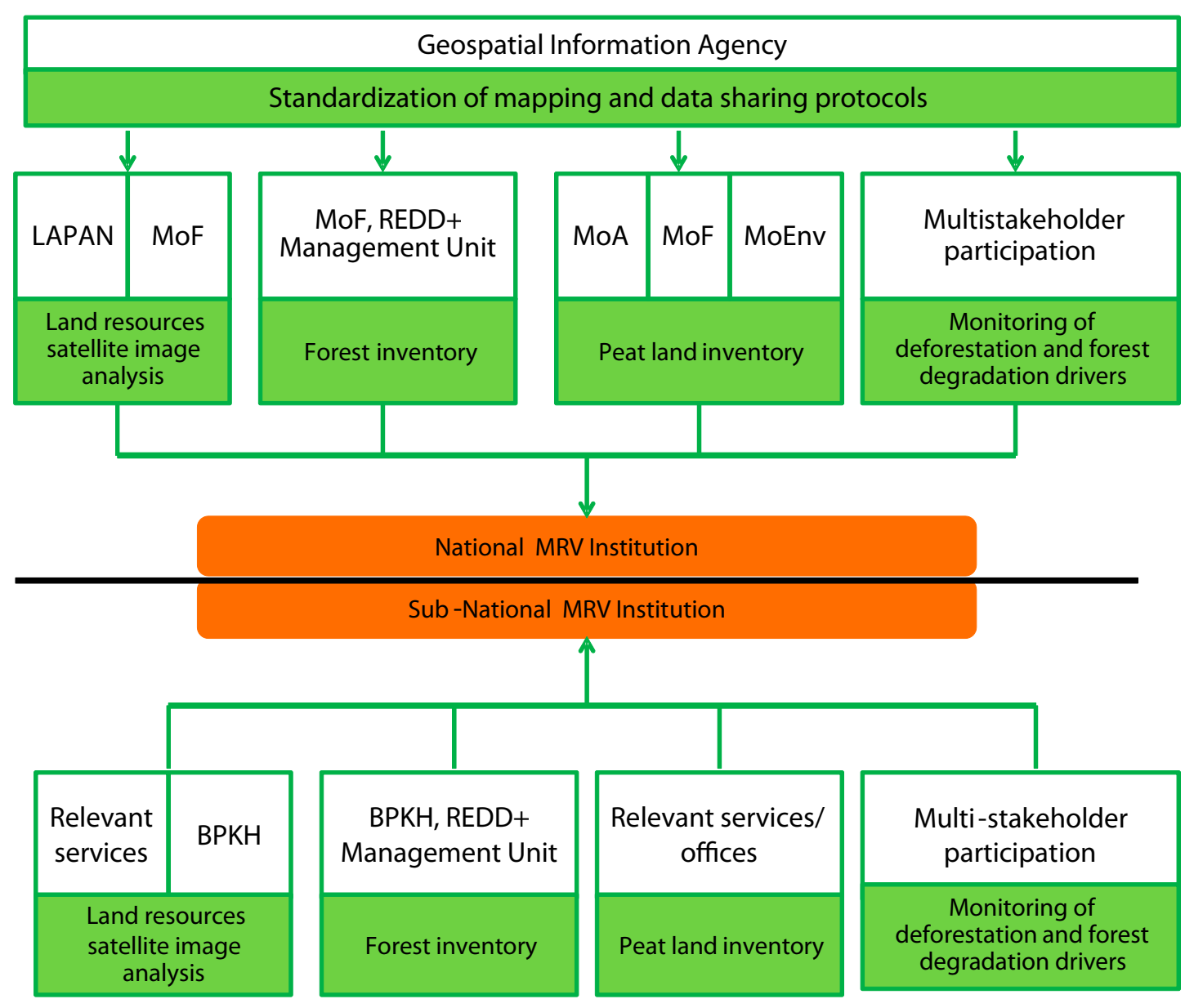

Figure 2. MRV Institution collects data from various ministries, agencies and stakeholders at the national and sub-national levels.

Notes:

LAPAN: Lembaga Penerbangan dan Antariksa Nasional (National Institute of Aeronautics and Space)

MoF: Ministry of Forestry

MoA: Ministry of Agriculture

MoEnv: Ministry of Environment

BPKH: Balai Pemantapan Kawasan Hutan (Agency for Forestry Area Consolidation)

Source: REDD+ Task Force (2013).

between institutions, limitations in human resources and competing interests in formulating land use policies.

The potential for local communities to participate in MRV activities, particularly in the measurement of carbon stocks and monitoring drivers of deforestation and degradation, has been recognized in the MRV strategy and implementation plan. However, the conditions and mechanisms that will enable the participation of local communities in MRV activities remain unclear.

\subsubsection{Establishment of REDD+ institutions}

The presidential regulation on the establishment of a national REDD+ administrative body (agency) became law on 2 September 2013 (Peraturan Presiden no. 62/2013). The duties and roles of the new REDD+ Agency are similar to those proposed in the REDD+ national strategy (see section 5.1.1). Although the process of establishing the REDD+ Funding Instrument and its roles are outlined in the regulation, the roles of the MRV Institution have not been well defined. The regulation states that REDD+ activities or projects under the coordination of the 
REDD + Agency will undertake the measurement and reporting activities, while the Ministry for Environment will conduct the verification (paragraph 24). This suggests that the MRV process will be managed by the REDD+ Agency, rather than by an independent MRV Institution as proposed in the national REDD+ strategies.

A recent presentation on FREDDI, at the Indonesia Meeting of the NORAD Focus on Civil Society Portfolio on Climate and Forestry 2013-2015, in Oslo on 28 October 2013, has shown the progress of FREDDI development (Sari 2013). The overall objectives of FREDDI are to:

- support emission reduction efforts

- support the implementation of the national REDD+ strategy

- support the work of the REDD+ Agency through a range of funding mechanisms

- promote a payment-for-performance approach

- provide complementary funding to the existing sources (such as the national and regional budgets or other donors)
- ensure that REDD+ funding is managed sustainably and effectively, disbursed and mobilized further.

Figure 3 shows the proposed structure of FREDDI and its relationships with other institutions. FREDDI will disburse funds through the following mechanisms:

- national programs that support REDD+ readiness to achieve national priorities and administer emergency interventions

- sub-national initiatives that support sub-national REDD+ strategies

- competitive grants for programs that promote sustainable forest and land use management

- small grants for low cost programs that strengthen community forestry, livelihoods and natural resource management.

The structure of FREDDI also shows that MRV data from the sub-national MRV level will be collected and verified by an MRV unit under the REDD+ Agency at the national level, rather than an

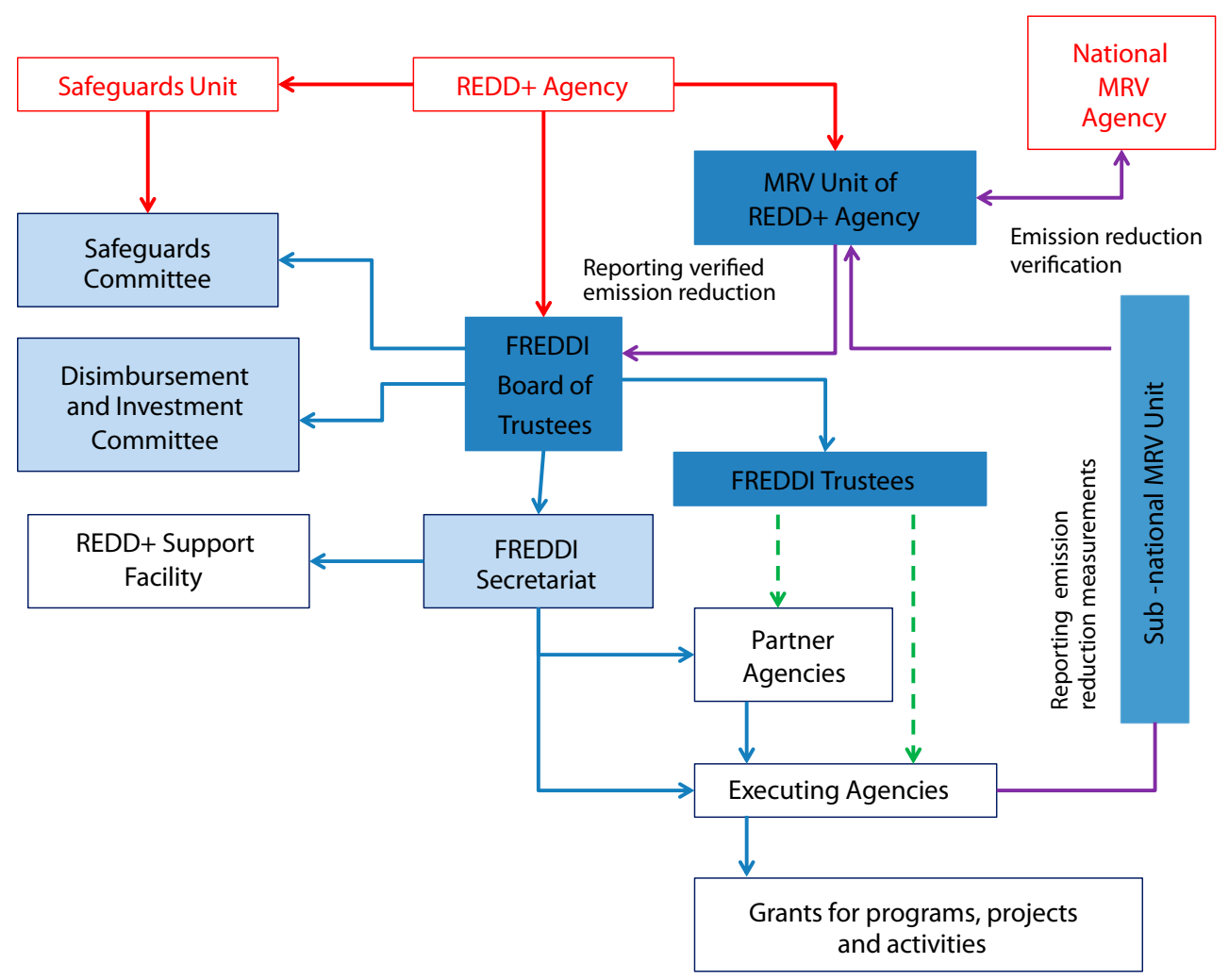

Figure 3. The organizational structure of FREDDI.

Source: Sari (2013). 
independent MRV institution at the national level (see Figure 1). In this scheme, the national MRV Agency will be responsible for verifying the reduction in emissions reported by the National MRV Unit. However, the establishment of the national MRV Agency has not been included in the presidential decree, while its proposed function, as outlined in the national REDD+ strategy, has largely been taken over by the MRV Unit under the REDD+ Agency. Thus, the institutional arrangement that manages the multi-level MRV system, including the need for independent verification, is likely to be a work in progress and can be expected to evolve over time.

\subsection{Current MRV implementation at the sub-national and local levels}

\subsubsection{Sub-national and province levels}

Central Kalimantan (Kalimantan Tengah) Province has been selected as a pilot province for REDD+ implementation in the partnership between the governments of Indonesia and Norway on REDD+. Approximately $70-80 \%$ of the landmass of the province consists of forests and peat swamp forests (Komisi Daerah REDD+ 2012). Deforestation and draining of peat swamp forests to reclaim land for agriculture have resulted in high susceptibility to forest fire and the release of GHG emissions from belowground carbon. The use of fire for land clearing in dry environments has also increased the risk of the fire escaping and spreading. Inconsistent land use planning has been a major issue since the decentralization of governance.

The provincial government of Central Kalimantan has formulated its regional REDD+ strategies (Komisi Daerah REDD+ 2012). One of the strategies is the application of MRV for the periodic assessment of forest and peat swamp forest resources. The subnational MRV Unit (i.e. at the provincial level) will monitor carbon measurements and non-carbon (environmental and social) data. The implementation of the 'One Map System' will synchronize and improve the basic map used for spatial planning, access to resources and solving disputes. Other strategies include increasing participation of local communities in forest management through policy reforms, introduction of a community-based forest management model, participatory mapping and incorporation of indigenous practices in peat swamp management.
The United Nations Collaborative Programme on REDD+ (UN-REDD+ Programme) was established in September 2008 to assist developing countries in building their capacity so they can participate in the REDD+ mechanism (UN-REDD 2010). The UN-REDD+ Programme for Indonesia selected Central Sulawesi as the pilot province for REDD+ implementation. The proposed REDD+ strategies for Central Sulawesi include the development of a Forest Management Unit (FMU) to provide an institutionalized setting for proper forest management, development of community forest plantations to restore forest cover in production forests, the rehabilitation of buffer zones in protected or conservation forests through community forestry, and the reallocation of plantations (timber and crops) to non-forest areas (Irawan 2012). The aim of the first three strategies is to increase the accountability of forest management through a formal local institution (FMU) and community-based forestry, which is expected to lead to more sustainable forest management. In contrast to these strategies, the REDD+ strategies for Central Kalimantan are mainly concerned with improving land use planning through a consistent planning system, moratorium on forest conversion, and the development of alternative livelihood programs by adding value to forest products, etc. The difference in REDD+ strategies reflects the different scales of deforestation and degradation in the two provinces: larger scale land use change and forest conversion occur more in Central Kalimantan than in Central Sulawesi.

\subsubsection{Local level}

A Demonstration Activity (DA) can be defined as a pilot feasibility study that aims to test and develop a methodology, technology and/or institution for the reduction of carbon emissions through avoiding deforestation and degradation (Mardiastuti 2012b). Strategies employed by DAs include the restoration of peat swamp forests and afforestation of deforested and degraded land. Demonstration Activities that have been conducted as feasibility studies or learning activities are usually of short duration $(<$ 5 years), while others have evolved as mediumterm projects with an implementation or crediting phase that spans 30 years (Mardiastuti 2012a). The uncertainties in the long-term financial incentives for REDD + activities, created by the absence of a new international climate agreement at COP15, may have contributed to the discontinuation of some projects beyond their feasibility or planning stage. 
Table 2. Examples of research projects that have implemented participatory measurement of carbon stocks in Indonesia

\begin{tabular}{|c|c|c|c|}
\hline Projects & Proponents in Indonesia & Locations & Activities \\
\hline $\begin{array}{l}\text { Community Carbon } \\
\text { Accounting (CAA) (Setyarso } \\
\text { 2012) }\end{array}$ & $\begin{array}{l}\text { Institute for Global } \\
\text { Environmental Strategies } \\
\text { (IGES), National Forestry } \\
\text { Council (DKN), Arupa }\end{array}$ & $\begin{array}{l}\text { Semoyo Village, } \\
\text { Gunung Kidul and } \\
\text { Terong Village, Bantul, } \\
\text { Yogyakarta; Burat } \\
\text { Village, Wonosobo, } \\
\text { Central Java; Talang } \\
\text { Tembago Village, } \\
\text { Merang, Jambi }\end{array}$ & $\begin{array}{l}\text { - Establishment of sampling } \\
\text { plots } \\
\text { - Measurements of above- } \\
\text { ground carbon stocks } \\
\text { - Measurements of litter } \\
\text { - Data compilation and analysis }\end{array}$ \\
\hline $\begin{array}{l}\text { Impact of Reducing } \\
\text { Emissions from } \\
\text { Deforestation and } \\
\text { Degradation (I-REDD) } \\
\text { (Rahayu et al. 2011) }\end{array}$ & $\begin{array}{l}\text { World Wide Fund (WWF), } \\
\text { World Agroforestry } \\
\text { Centre (ICRAF), NORDECO }\end{array}$ & $\begin{array}{l}\text { Batu Majang Village, } \\
\text { Kutai Barat, East } \\
\text { Kalimantan }\end{array}$ & $\begin{array}{l}\text { Establishment of sampling } \\
\text { plots } \\
\text { - Measurements of above- } \\
\text { ground carbon stocks } \\
\text { - Species identification }\end{array}$ \\
\hline $\begin{array}{l}\text { Community Based Forest } \\
\text { Management (CBFM) } \\
\text { (FORCLIME 2013a) }\end{array}$ & $\begin{array}{l}\text { Deutsche Gesellschaft } \\
\text { für Internationale } \\
\text { Zusammenarbeit (GIZ), } \\
\text { Ministry of Forestry }\end{array}$ & $\begin{array}{l}\text { Setulang Village, } \\
\text { Malinau, East } \\
\text { Kalimantan }\end{array}$ & - Participatory forest inventory \\
\hline
\end{tabular}

Most medium-term DA projects have been, or are planned to be, registered as Voluntary Carbon Standard (VCS), CCBA or Plan Vivo projects that enable them to benefit from the voluntary carbon market.

There were approximately $41 \mathrm{DA}$ projects in Indonesia distributed in 14 provinces. Appendix 1 lists DAs that have been obtained from various databases: the REDD Desk, IGES REDD+ database, project listings on the Indonesian Ministry of Forestry website (http://www.redd-indonesia. org/proyek-percontohan) and global database based on CIFOR's Comparative Global Study (http:// www.forestclimatechange.org/redd-map/). Repeated listings of the same project were removed whenever possible.

Participatory measurements of aboveground carbon stocks and litter have been implemented in Indonesia through several research projects (Table 2). The measurement activities were conducted in the context of attempts at increasing local capacity in community-based forest management (Setyarso 2012; FORCLIME 2013a) and/or exploring the feasibility of participatory carbon stock measurements (Rahayu et al. 2011; Setyarso 2012). The ability of local communities to measure carbon stocks (Rahayu et al. 2011; Setyarso 2012) and retain the measurement skills (Setyarso 2012) have been reported.
The participatory measurement of carbon stocks in the Community Carbon Accounting (CAA) project has delivered many benefits for the local communities: improved timber harvesting plan and timber value in the areas with village forest management, increased organizational skills of the participants, built local capacity to inform and train others, and increased awareness of environmental issues (Setyarso 2012, pers.comm). The project has also reported that the capacity of local communities to understand the carbon measurement contexts (e.g. climate change and GHG emissions) and techniques (e.g. mapping, basal area measurements) varied between geographical locations (Setyarso 2012). However, the project report did not elaborate whether the differences can be explained by socioeconomic and environmental conditions of the communities.

In contrast, the progress reports and project design documents of some DA projects (KFCP 2009; Bolick et al. 2011; GIZ 2011; WWF-Indonesia 2012) indicated that carbon measurement activities were planned and performed by professional staff, with limited or no local community participation (e.g. providing labor). This confirms the findings of Danielsen et al. (2013) that approximately half of CCBA projects did not plan to involve local communities in their monitoring activities. Based on our interviews with several project proponents (see Appendix 2), they cited the followings barriers 
or challenges to greater involvement of local communities in MRV activities:

- demanding measurement techniques in peat swamp forests

- limited capacity to produce high quality data.

Although the technical barriers for PMRV may be overcome with greater investment in training, there is not a strong financial incentive for the DA project proponents to implement it. The cost of PMRV can be lower than the cost of a professional survey when repeated measurements, such as annual assessments, are conducted over the lifetime of the project (Danielsen et al. 2013). DA projects are required to perform an initial biomass assessment to quantify GHG emissions for the baseline scenario or Reference Emission Level (REL), but the cost of a professional survey for this assessment may be lower than the initial training cost of local communities. Under VCS, the project proponents are required to conduct carbon stock monitoring from a field survey once in every five years. Thus, the total number of measurements is relatively small and PMRV may not be cost effective.

Several DA projects have been implemented in areas where some community members may have contributed to deforestation and degradation through illegal logging (KFCP 2009; Bolick et al. 2011; GIZ 2011; WWF-Indonesia 2012). In these cases, the benefits of monitoring need to be established, although significant efforts may be required to transform the mindset of the communities from exploitative to sustainable resource use and to support alternative livelihood programs. A sustainable PMRV can be implemented if the benefits of monitoring (and increasing) carbon stocks exceed the opportunity costs for the local communities.

\subsection{Opportunities and challenges in developing PMRV}

Community-based forest management provides an ideal opportunity for the implementation of PMRV. Data collected through PMRV can be used for sustainable forest management and documenting changes in carbon stocks for REDD+. The alignment of MRV objectives with the interest of the local community in monitoring changes in carbon stocks for management purposes is a strong incentive for the sustainability of a PMRV program, which can also be challenging to establish. This suggests that
PMRV can be a useful tool for sustainable forest management outside the context of REDD+ by providing data for better management outcomes.

Policies and regulations that support communitybased forest management can encourage greater participation of local communities in sustainable forest management and MRV (Klooster and Masera 2000; Chhatre and Agrawal 2009; Porter-Bolland et al. 2012). In Indonesia, forest management units (FMUs) are being established as an operational unit at the district level that implements long-term, sustainable management plans to achieve economic, social and ecological management objectives (FORCLIME 2013c). This may improve the engagement between local communities and forestry agencies that results in better forest management. The management area of each FMU can cover a range of land uses and forest management types, including community-based forest management. A PMRV approach for carbon stocks can be, therefore, embedded in the FMU system. The proposed District Forest Management Information System (DFMIS) that will collect forest inventory data at the FMU level can act as a registry for collecting carbon stock data obtained through PMRV (Figure 4).

There are still challenges in implementing PMRV in Indonesia. A PMRV approach may not work or be sustainable in areas where local communities do not have access to or management rights of forest resources. Unclear regulations on certain types of community-based forest management schemes (customary forest, people's forest), land tenure conflicts and spatial planning that overlap (Indrarto et al. 2012) need to be resolved to provide a secured framework for sustainable forest management and PMRV. The diversity in land use practices, forest conditions and the capacity of local institutions implies that a customized PMRV approach may be needed for each project site. This can be achieved by taking into account the local biophysical and socio-economic conditions, as well as involving local communities in the design and implementation of PMRV (Hartanto et al. 2002; Danielsen et al. 2005a; Setyarso 2012).

The sustainability of PMRV and successful integration of the collected data into the national MRV system require the involvement and support of government agencies at various levels (Danielsen et al. 2005b; Poulsen and Luanglath 2005; StuartHill et al. 2006). This involvement could include 


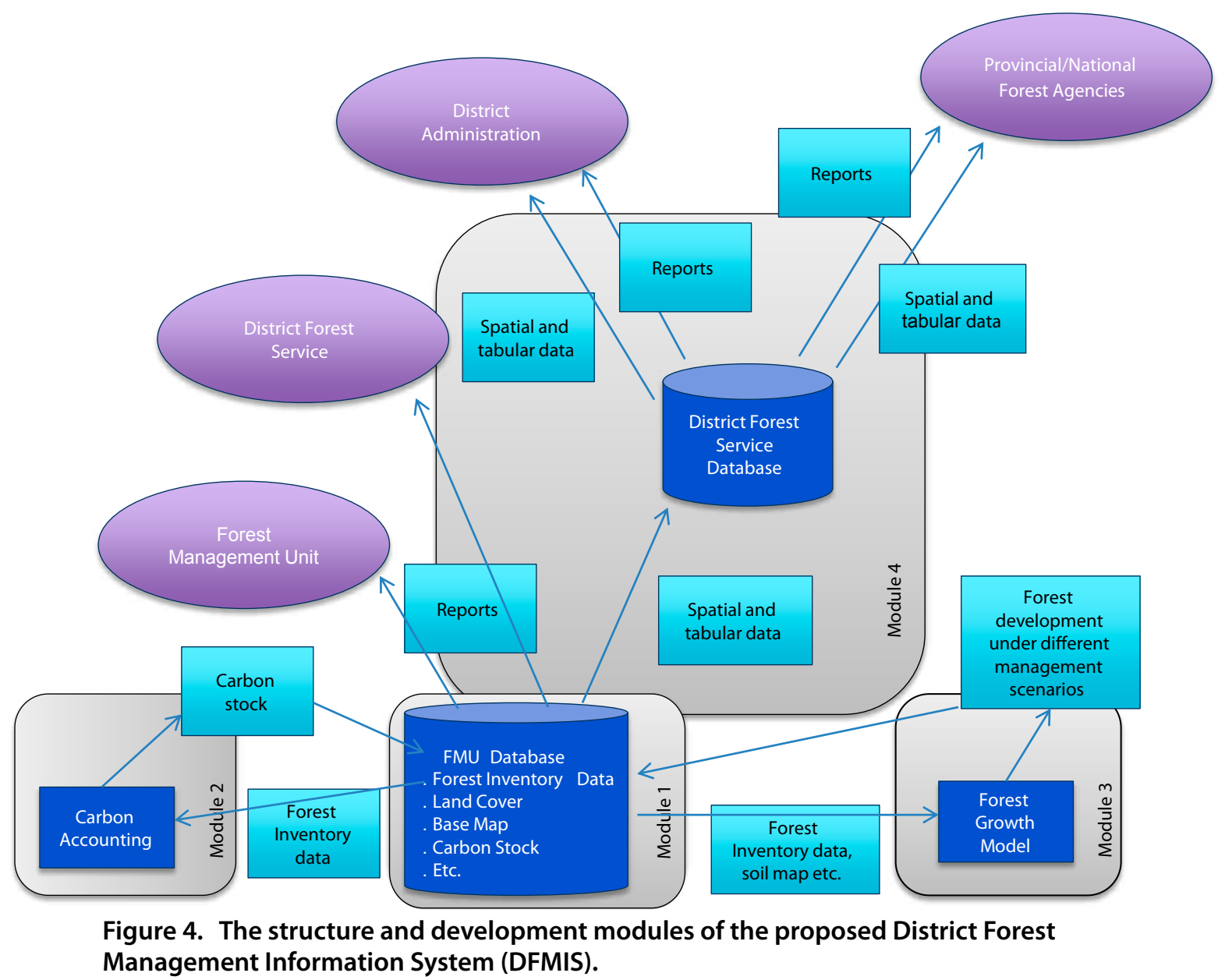

Source: FORCLIME (2013b).

training and ongoing support for measurements, establishing a robust reporting protocol and system, and transparent and collaborative decision making. The lack of capacity and resources to perform those tasks must be overcome by government agencies.

Several studies have proposed that local communities should receive financial compensation for PMRV activities (Graham and Thorpe 2009; Skutsch et al. 2009; Fry 2011), which may bring additional income for the local communities. However, there are several considerations that must be taken into account if this model is to be adopted. The distribution of the financial compensation must be fair (rewarding those who perform the work), but it should not create inequity amongst community groups due to limited opportunity to participate. The cost of PMRV may be offset against the expected financial compensation from emission reductions, although the uncertainties about the long-term REDD+ funding arrangements may cause a delay in accessing financial compensation. Any funding that will be available for ongoing PMRV activities is likely to be small if cost-efficiency is one of the justifications for PMRV. It may be more efficient to use this fund for capacity building activities (e.g. training, facilitating community meetings, equipment costs). For example: the proposed funding mechanism in FREDDI provides small grants for capacity building activities in local communities (Sari 2013), which may be used to cover training or other costs of PMRV. 


\section{Discussion and conclusion}

The design and implementation of PMRV may benefit from the extensive research and application of participatory monitoring of natural resources and biodiversity. The important lessons learnt from participatory monitoring include the potential incentives required for participation, factors that may contribute to the sustainability of the program and upscaling of the monitoring program. However, participatory monitoring and PMRV have different aims and requirements. A successful participatory monitoring program collects local data that are aligned with the interests of local communities to improve local management decisions that benefit them. The objectives of PMRV are to collect local carbon stock data to improve carbon accounting at the national level and increase the participation of local communities to maximize the co-benefits of REDD+. PMRV has specific requirements for the data collection methods, reporting and data quality control that must be accepted and agreed to by the international community. The implementation of PMRV should take into account the conditions that are conducive for participatory monitoring, but the strategies that contribute to the success of participatory monitoring may need to be modified and adapted to the requirements of MRV.

Based on the findings from the literature review, the implementation of sustainable PMRV requires the following conditions:

1. PMRV needs to be embedded into communitybased forest management so the carbon stock data can be used to improve management decisions as well as estimate GHG emissions reduction. The combined PMRV and community-based forest management program can deliver economic, social and environmental benefits for the local communities, such as improving livelihoods, building human and organizational capacity, increasing negotiating skills, increasing environmental awareness, strengthening ecosystem services and conserving biodiversity.

2. Robust participatory reporting methods and reliable validation processes need to be identified, as the success of PMRV depends on reporting and verification (or validation) activities as well as measurement activities.

3. PMRV should be incorporated into the multilevel MRV system, national forest inventory and management systems. This can be done by taking advantage of the restructuring and/or development of forest inventory and management systems that have already been conducted to prepare for REDD+ implementation in many REDD+ participating countries.

4. The potential contribution of PMRV to maximize the co-benefits of REDD+ and implement REDD+ safeguards should be recognized as an important incentive, while acknowledging that further research may still be required to ensure the social and environmental benefits of PMRV can be realized. This incentive may increase the adoption and implementation of PMRV by the local REDD+ project proponents, as some proponents have not been persuaded to adopt PMRV based on its potential to lower the cost of MRV activities.

The development of the MRV system in Indonesia has provided an opportunity to examine the feasibility of implementing the PMRV approach and its integration into the MRV system. Policies and initiatives that can supports PMRV (such as recognition of the PMRV approach in the national MRV strategy, legislation that support community forestry, establishment of FMUs) have been implemented. However, the structure of the multi-level MRV system has yet to be finalized. There are several flaws in the current format of the MRV Unit under the REDD+ Agency (i.e. a lack of independence, the role of the National MRV Agency has been reduced to verifying emissions reduction), so the information flow into and within the multi-level MRV system is still vague. Thus, the institutional framework to support PMRV has begun, but it has yet to be tested.

We recommend that PMRV for carbon and noncarbon data be developed and implemented in community-based forest management schemes. In 
forest areas where local communities do not have access or management rights, the development of PMRV (and REDD+) may require preliminary work to create positive incentives (e.g. direct payment) for sustainable forest management. The PMRV activities should be carried out as a partnership between the local communities, local institutions, government agencies at the district level, such as FMU, the MRV Unit at the provincial level and its counterpart at the national level. This will result in a well-supported PMRV and the collected data aggregated at the national level. 


\section{References}

Angelsen A, Streck C, Peskett L, Brown J and Luttrell C. 2008 What is the right scale for REDD? In Anglesen A. Moving ahead with REDD: Issues, options and implications. Bogor, Indonesia: Center for International Forestry Research. 31-40.

Angelsen A, Brockhaus M, Kanninen M, Sills E, Sunderlin WD and Wertz-Kanounnikoff S. 2009. Realising REDD+: National strategy and policy options. Bogor, Indonesia: Center for International Forestry Research.

Angelsen A, Brockhaus M, Sunderlin WD and Verchot LV. 2012. Analysing REDD+: Challenges and choices. Bogor, Indonesia: Center for International Forestry Research

Asner GP, Powell GVN, Mascaro J, Knapp DE, Clark JK, Jacobson J, Kennedy-Bowdoin T, Balaji A, Paez-Acosta G, Victoria E, et al. 2010. High-resolution forest carbon stocks and emissions in the Amazon, Proceedings of the National Academy of Sciences of the United States of America, 107(38): 16738-16742.

Baccini A, Goetz SJ, Walker WS, Laporte NT, Sun M, Sulla-Menashe D, Hackler J, Beck PSA, Dubayah R, Friedl MA et al. 2012. Estimated carbon dioxide emissions from tropical deforestation improved by carbon-density maps, Nature Climate Change, 2(3): 182-185.

Bolick L, Lemons T, Procanik J, Reece J and Faud F. 2011. Rimba Raya biodiversity reserve project project document. Central Kalimantan, Indonesia: Infinite Earth - Rimba Raya Conservation. 148.

Brewster J, Bradley A and Yeang D. 2011. Community-based monitoring, reporting and verification (MRV): An Assessment in the Oddar Meanchey Community Forestry REDD+ Site, Cambodia. Cambodia: Pact Cambodia. 32.

Burgess ND, Bahane B, Clairs T, Danielsen F, Dalsgaard S, Funder M, Hagelberg N, Harrison P, Haule C, Kabalimu K, et al. 2010. Getting ready for REDD+ in Tanzania: A case study of progress and challenges, Oryx, 44(03): 339-351.

Chhatre A and Agrawal A 2009. Trade-offs and synergies between carbon storage and livelihood benefits from forest commons, Proceedings of the
National Academy of Sciences of the United States of America, 106(42): 17667-17670.

Constantino PDL, Carlos HSA, Ramalho EE, Rostant L, Marinelli CE, Teles D, Fonseca SF, Fernandes RB and Valsecchi J 2012.

Empowering local people through communitybased resource monitoring: A comparison of Brazil and Namibia, Ecology and Society, 17(4).

Danielsen F, Adrian T, Brofeldt S, van Noordwijk M, Poulsen MK, Rahayu S, Rutishauser E, Theilade I, Widayati A, An NT, et al. 2013. Community monitoring for REDD plus : International promises and field realities, Ecology and Society, 18(3).

Danielsen F, Burgess ND and Balmford A 2005a. Monitoring matters: Examining the potential of locally-based approaches, Biodiversity and Conservation, 14(11): 2507-2542.

Danielsen F, Jensen AE, Alviola PA, Balete DS, Mendoza M, Tagtag A, Custodio C and Enghoff M 2005b. Does monitoring matter? A quantitative assessment of management decisions from locally-based monitoring of protected areas, Biodiversity and Conservation, 14(11): 2633-2652.

Danielsen F, Burgess ND, Balmford A, Donald PF, Funder M, Jones JPG, Alviola P, Balete DS, Blomley T, Brashares J, et al. 2009. Local participation in natural resource monitoring: a characterization of approaches, Conservation Biology, 23(1): 31-42.

Danielsen F, Skutsch M, Burgess ND, Jensen PM, Andrianandrasana H, Karky B, Lewis R, Lovett JC, Massao J, Ngaga Y, et al. 2011. At the heart of REDD+: A role for local people in monitoring forests?, Conservation Letters, 4(2): 158-167.

DeFries R, Achard F, Brown S, Herold M, Murdiyarso D, Schlamadinger B and de Souza C 2007. Earth observations for estimating greenhouse gas emissions from deforestation in developing countries, Environmental Science \& Policy, 10(4): 385-394.

Evans K and Guariguata MR. 2008. Participatory monitoring in tropical forest management: $A$ review of tools, concepts and lessons learned. Bogor, 
Indonesia: Center for International Forestry Research.

[FFI] Fauna \& Flora International. 2012. Community forest ecosystem services, Indonesia - Plan Vivo project idea note. Jakarta, Indonesia: Fauna \& Flora International. 24.

[FORCLIME] Forests and Climate Change Programme. 2013a. Community based forest management. FORCLIME TC Module Briefing Note. Jakarta, Indonesia: Forests and Climate Change Programme 6: 4.

[FORCLIME] Forests and Climate Change Programme. 2013b. Support for the Setup of a District Forest Management Information System (DFMIS). FORCLIME TC Module Briefing Note. Jakarta, Indonesia: Forests and Climate Change Programme 8: 2.

[FORCLIME] Forests and Climate Change Programme. 2013c. Support for Forest Management Unit at the District Level. FORCLIME TC Module Briefing Note. Jakarta, Indonesia: Forests and Climate Change Programme 2: 2 .

Fry BP 2011. Community forest monitoring in REDD+: The 'M' in MRV?, Environmental Science \& Policy, 14(2): 181-187.

Garcia CA and Lescuyer G 2008. Monitoring, indicators and community based forest management in the tropics: Pretexts or red herrings?, Biodiversity and Conservation, 17(6): 1303-1317.

[GIZ] Deutsche Gesellschaft für Internationale Zusammenarbeit. 2011. Merang REDD Pilot Project (MRPP) summary of results and achievements. Jakarta, Indonesia: Gesellschaft für Internationale Zusammenarbeit. 59.

[GOFC-GOLD] Global Observation of Forest and Land Cover Dynamics, Land Cover Project Office. 2012. A sourcebook of methods and procedures for monitoring and reporting anthropogenic greenhouse gas emissions and removals associated with deforestation, gains and losses of carbon stocks in forests remaining forests, and forestation. Netherlands: Wageningen University. 219.

Graham K and Thorpe A 2009. Community-based monitoring, reporting and verification of REDD projects: Innovative potentials for benefit sharing, Carbon \& Climate Law Review, 3(3): 303-313.
Harris NL, Brown S, Hagen SC, Saatchi SS, Petrova S, Salas W, Hansen MC, Potapov PV and Lotsch A 2012. Baseline map of carbon emissions from deforestation in tropical regions. Science 336(6088): 1573-1576.

Hartanto H, Lorenzo MCB and Frio AL 2002. Collective action and learning in developing a local monitoring system, International Forestry Review, 4(3): 184-195.

Herold M and Skutsch MM. 2009 Measurement, reporting and verification for REDD+:

Objectives, capacities and institutions. In Angelsen A, Brockhaus M, Kanninen M, Sills E, Sunderlin WD and Wertz-Kanounnikoff S. Realising REDD+: National strategy and policy options. Bogor, Indonesia: Center for International Forestry Research. 84-100.

Indrarto GB, Murharjanti P, Khatarina J, Pulungan I, Ivalerina F, Rahman J, Prana MN, Resosudarmo IAP and Muharrom E. 2012. The context of REDD + in Indonesia: Drivers, agents, and institutions. Bogor, Indonesia: CIFOR. 116.

[IPCC] Intergovernmental Panel on Climate Change. 2006 Volume 4: Agriculture, rorestry and other land use. In Eggleston S, Buendia L, Miwa K, Ngara T and Tanabe K. 2006 IPCC guidelines for national greenhouse gas inventories. Hayama, Japan: Intergovernmental Panel on Climate Change.

[IPCC] Intergovernmental Panel on Climate Change. 2003. Good practice guidance on land use, landuse change and forestry. Penman J, Gytarsky M, Hiraishi T, Krug T, Kruger D, Pipatti R, Buendia L, Miwa K, Ngara T, Tanabe K and Wagner F (eds). Hayama, Japan: Institute for Global Environmental Strategies.

Irawan S. 2012. Provincial REDD+ implementation plan Central Sulawesi. Jakarta, Indonesia: UN-REDD Programme Secretariat - Kemenhut RI. 56.

[KFCP] Kalimantan Forest and Climate Partnership. 2009. Kalimantan Forest and Climate Partnership (KFCP) design document. Central Kalimantan, Indonesia: Indonesia-Australia Forest Carbon Partnership. 133.

Klooster D and Masera O 2000. Community forest management in Mexico: carbon mitigation and biodiversity conservation through rural development, Global Environmental Change Human and Policy Dimensions, 10(4): 259-272. 
Komisi Daerah REDD+ 2012. Strategi daerah REDD+ Provinsi Kalimantan Tengah. Central Kalimantan, Indonesia: Komisi Daerah REDD+. 160.

Korhonen-Kurki K, Brockhaus M, Duchelle AE, Atmadja S and Pham TT. 2012 Multiple levels and multiple challenges for REDD+. In Angelsen A, Brockhaus M, Sunderlin WD and Verchot L. Analysing REDD+: Challenges and Choices. Bogor, Indonesia: Center for International Forestry Research 91-110.

Lawrence A, Paudel K, Barnes R and Malla Y 2006. Adaptive value of participatory biodiversity monitoring in community forestry, Environmental Conservation, 33(4):325-334.

Mardiastuti A. 2012a Main report. In Mardiastuti A. The role of UN-REDD in the Development of $R E D D+$ in Indonesia. Jakarta, Indonesia: UNREDD Programme Indonesia.

Mardiastuti A. 2012b Highlight of REDD+ related projects in Indonesia. In Mardiastuti A. The role of UN-REDD in the Development of REDD + in Indonesia. Jakarta: UN-REDD Programme Indonesia.

Mukama K, Mustalahti I and Zahabu E 2012. Participatory forest carbon assessment and REDD+: learning from Tanzania, International Journal of Forestry Research, 2012: 126454.

Murdiyarso D and Skutsch M. 2006. Community forest management as a carbon mitigation option: Case studies. Bogor, Indonesia: Center for International Forestry Research.

Porter-Bolland L, Ellis EA, Guariguata MR, RuizMallen I, Negrete-Yankelevich S and ReyesGarcia V 2012. Community managed forests and forest protected areas: An assessment of their conservation effectiveness across the tropics, Forest Ecology and Management, 268: 6-17.

Poulsen MK and Luanglath K 2005. Projects come, projects go: Lessons from participatory monitoring in southern Laos, Biodiversity and Conservation, 14(11): 2591-2610.

Pratihast AK, Herold M, De Sy V, Murdiyarso D and Skutsch M 2013. Linking communitybased and national REDD plus monitoring: a review of the potential, Carbon Management, 4(1): 91-104.
Rafli TP, Usher G and Niles JO. 2007. Reducing carbon emissions from deforestation in the Ulu Masen Ecosystem, Aceh, Indonesia - a triplebenefit project design note for CCBA audit. Aceh, Indonesia: Provincial Government of Aceh. 67.

Rahayu S, Poulsen M, Kurniawan Y and Hultera 2011. Monitoring cadangan karbon oleh masyarakat: Uji coba di Propinsi Kalimantan Timur, Indonesia dan Nghe An, Vietnam, Kiprah Agroforestri 10, 4(3): 10-12.

REDD+ Task Force. 2013. Strategy and implementation plan for REDD+ measurement, reporting, and verification (MRV) in Indonesia. Jakarta, Indonesia: REDD+ Task Force. 106.

REDD+ Task Force. 2012. REDD+ national strategy. Jakarta, Indonesia: REDD+ Task Force. 40.

Romijn E, Herold M, Kooistra L, Murdiyarso $\mathrm{D}$ and Verchot L 2012. Assessing capacities of non-Annex I countries for national forest monitoring in the context of REDD+, Environmental Science \& Policy, 19/20: 33-48.

Sari AP. 2013. FREDDI pipeline portfolio: A work in progress.InIndonesia Meeting - Civil Society Department of NORAD Oslo: President's Delivery Unit for Development Monitoring and Oversight (UKP4).

Setyarso A. 2012. Community Carbon Accounting Action research project - Indonesia FY2011 summary report. Japan: Institute for Global Environmental Strategies - National Forestry Council of Indonesia. 13.

Sheil D and Lawrence A. 2004. Tropical biologists, local people and conservation: new opportunities for collaboration, Trends in Ecology \& Evolution, 19(12): 634-638.

Skutsch MM, van Laake PE, Zahabu EM, Karky BS and Phartiyal P. 2009 Community monitoring in REDD+. In Angelsen A, Brockhaus M, Kanninen M, Sills E, Sunderlin WD and Wertz-Kanounnikoff S. Realising REDD+: National strategy and policy options. Bogor, Indonesia: Center for International Forestry Research. 101-112.

Stuart-Hill G, Diggle R, Munali B, Tagg J and Ward D 2006. The event book system: community-based monitoring in Namibia, Participatory Learning and Action(55): 70-78. 
Topp-Jorgensen E, Poulsen MK, Lund JF and Massao JF 2005. Community-based monitoring of natural resource use and forest quality in montane forests and miombo woodlands of Tanzania, Biodiversity and Conservation, 14(11): 2653-2677.

UN-REDD. 2010. The UN-REDD programme strategy 2011-2015. Geneva, Switzerland: UNREDD Programme Secretariat. 22.
[WWF] World Wide Fund for Nature - Indonesia. 2012. Rewetting of tropical peat swamp forest in Sebangau National Park, Central Kalimantan, Indonesia - project design document. Sebangau, Central Kalimantan, Indonesia: World Wide Fund for Nature - Indonesia. 71. 


\section{Appendix 1. REDD+ demonstration activities in Indonesia}

\begin{tabular}{|c|c|c|c|}
\hline Project name & Province & Organization & Aims $^{a}$ \\
\hline Leuser Ecosystem REDD Project & Aceh & Global EcoRescue Government of Aceh & $A D$ \\
\hline \multirow{3}{*}{$\begin{array}{l}\text { Reducing Carbon Emissions from } \\
\text { Deforestation in the Ulu Masen } \\
\text { Ecosystem }\end{array}$} & \multirow[t]{3}{*}{ Aceh } & Aceh Provincial Government & \multirow[t]{3}{*}{$A D, A d g$} \\
\hline & & Carbon Conservation & \\
\hline & & Flora \& Fauna International & \\
\hline \multirow[t]{4}{*}{ Batang Toru REDD+ Project } & \multirow{4}{*}{$\begin{array}{l}\text { North } \\
\text { Sumatra }\end{array}$} & Conservation International & \multirow[t]{4}{*}{$A D$} \\
\hline & & USAID & \\
\hline & & Australian mining concession & \\
\hline & & Yayasan Ecosystem Lestari & \\
\hline \multirow[t]{2}{*}{ Kampar Carbon Reserve } & \multirow[t]{2}{*}{ Riau } & Asian Pulp and Paper & \multirow[t]{2}{*}{$A D$} \\
\hline & & Carbon Conservation & \\
\hline Kampar Ring & Riau & $\begin{array}{l}\text { Asia Pacific Resources International } \\
\text { Limited }\end{array}$ & AD, Adg, RS \\
\hline \multirow[t]{2}{*}{ Tesso Nilo Pilot Project } & \multirow[t]{2}{*}{ Riau } & World Wide Fund & \multirow{2}{*}{$\begin{array}{l}\text { AD, Adg, RS, } \\
\text { AF }\end{array}$} \\
\hline & & Tesso Nillo National Park & \\
\hline Siberut Project & West Sumatra & Global Green & $\mathrm{N} / \mathrm{A}$ \\
\hline Sumatra Forest Carbon Partnership & Jambi & $\begin{array}{l}\text { Australian - Indonesian Governments } \\
\text { Partnership }\end{array}$ & $\begin{array}{l}\text { AD, Adg, RS, } \\
A F\end{array}$ \\
\hline \multirow[t]{2}{*}{ Berbak Carbon Value Initiative } & \multirow[t]{2}{*}{ Jambi } & Zoology Society of London & \multirow[t]{2}{*}{$A D$} \\
\hline & & $\begin{array}{l}\text { Department for Environment, Food and } \\
\text { Rural Affairs (UK) }\end{array}$ & \\
\hline \multirow[t]{3}{*}{ Community Carbon Pool (Jambi) } & \multirow[t]{3}{*}{ Jambi } & Fauna \& Flora International & \multirow[t]{3}{*}{$A D$} \\
\hline & & Darwin Initiative & \\
\hline & & World Agroforestry Centre & \\
\hline \multirow[t]{3}{*}{ Harapan Rainforest Project } & \multirow[t]{3}{*}{ Jambi } & Burung Indonesia & \multirow[t]{3}{*}{$A D, A F$} \\
\hline & & $\begin{array}{l}\text { The Royal Society for the Protection of } \\
\text { Birds }\end{array}$ & \\
\hline & & Birdlife International & \\
\hline \multirow[t]{3}{*}{ Lebong Carbon Conservation Program } & \multirow[t]{3}{*}{ Bengkulu } & Artha Suaka Foundation & \multirow[t]{3}{*}{$A D, A d g, A F$} \\
\hline & & District government & \\
\hline & & Carbon Conservation & \\
\hline Merang REDD+ Pilot Project (MRPP) & $\begin{array}{l}\text { South } \\
\text { Sumatra }\end{array}$ & $\begin{array}{l}\text { Gesellschaft für Internationale } \\
\text { Zusammenarbeit }\end{array}$ & $A D, A d g, R S$ \\
\hline \multirow{2}{*}{$\begin{array}{l}\text { Danau Siawan-Belida Ecological } \\
\text { Restoration Concession/ Conservation of } \\
\text { the Upper Kapuas Lakes System }\end{array}$} & West & Fauna \& Flora International & \multirow[t]{2}{*}{$A D, A d g, R S$} \\
\hline & Kalimantan & Macquarie Bank & \\
\hline \multirow{4}{*}{$\begin{array}{l}\text { FORCLIME - Kapuas Hulu Demonstration } \\
\text { Activity }\end{array}$} & \multirow{4}{*}{$\begin{array}{l}\text { West } \\
\text { Kalimantan }\end{array}$} & Kreditanstalt für Wiederaufbau & $A D, A d g$ \\
\hline & & $\begin{array}{l}\text { Gesellschaft für Internationale } \\
\text { Zusammenarbeit }\end{array}$ & \\
\hline & & Ministry of Forestery & \\
\hline & & District and provincial governments & \\
\hline
\end{tabular}


Appendix 1. Continued

\begin{tabular}{|c|c|c|c|}
\hline Project name & Province & Organization & Aims $^{a}$ \\
\hline $\begin{array}{l}\text { Rehabilitation of the Sungai Putri peat } \\
\text { swamp forest, Ketapang, Kalimantan }\end{array}$ & $\begin{array}{l}\text { West } \\
\text { Kalimantan }\end{array}$ & $\begin{array}{l}\text { Fauna \& Flora International } \\
\text { Macquarie Bank }\end{array}$ & $\mathrm{AD}, \mathrm{Adg}, \mathrm{RS}$ \\
\hline $\begin{array}{l}\text { Community Carbon Pool (West } \\
\text { Kalimantan) }\end{array}$ & $\begin{array}{l}\text { West } \\
\text { Kalimantan }\end{array}$ & $\begin{array}{l}\text { Fauna \& Flora International } \\
\text { Packard Foundation }\end{array}$ & AD, Adg, RS \\
\hline $\begin{array}{l}\text { Community carbon project for } \\
\text { Lamandau Wildlife Reserve }\end{array}$ & $\begin{array}{l}\text { Central } \\
\text { Kalimantan }\end{array}$ & $\begin{array}{l}\text { World Agroforestry Centre } \\
\text { Rare Conservation } \\
\text { Yayasan Orangutan Indonesia } \\
\text { Orangutan Foundation (UK) } \\
\text { Clinton Foundation }\end{array}$ & $A D, A d g, R S$ \\
\hline $\begin{array}{l}\text { Kalimantan Forest and Climate } \\
\text { Partnership }\end{array}$ & $\begin{array}{l}\text { Central } \\
\text { Kalimantan }\end{array}$ & $\begin{array}{l}\text { Australian Government } \\
\text { CARE } \\
\text { Borneo Orangutan Survival } \\
\text { Wetlands International }\end{array}$ & $\begin{array}{l}A D, A d g, R S, \\
A F\end{array}$ \\
\hline $\begin{array}{l}\text { Katingan Conservation Area: A Global } \\
\text { Peatland Capstone Project }\end{array}$ & $\begin{array}{l}\text { Central } \\
\text { Kalimantan }\end{array}$ & Starling Resources & $\begin{array}{l}\text { AD, Adg, RS, } \\
\text { AF }\end{array}$ \\
\hline $\begin{array}{l}\text { Mawas Peatland Conservation Area } \\
\text { Project (Orangutan PCAP in Central } \\
\text { Kalimantan) }\end{array}$ & $\begin{array}{l}\text { Central } \\
\text { Kalimantan }\end{array}$ & $\begin{array}{l}\text { Orangutan Conservancy } \\
\text { The Dutch Royal Government } \\
\text { Winrock International } \\
\text { Shell Canada }\end{array}$ & $A D, A d g, R S$ \\
\hline Sebangau National Park & $\begin{array}{l}\text { Central } \\
\text { Kalimantan }\end{array}$ & $\begin{array}{l}\text { World Wide Fund } \\
\text { Borneo Orangutan Survival } \\
\text { Wetlands International } \\
\text { CARE }\end{array}$ & $\mathrm{RS}, \mathrm{AD}$ \\
\hline $\begin{array}{l}\text { The Rimba Raya Biodiversity Reserve } \\
\text { Project }\end{array}$ & $\begin{array}{l}\text { Central } \\
\text { Kalimantan }\end{array}$ & $\begin{array}{l}\text { Infinite Earth } \\
\text { Orangutan Foundation (UK) }\end{array}$ & $A D, A d g, R S$ \\
\hline $\begin{array}{l}\text { Berau, Indonesia Climate Action Project; } \\
\text { Kabupaten Berau Forest Carbon Program }\end{array}$ & $\begin{array}{l}\text { East } \\
\text { Kalimantan }\end{array}$ & $\begin{array}{l}\text { The Nature Conservancy } \\
\text { World Agroforestry Centre } \\
\text { Sekala } \\
\text { Winrock International } \\
\text { University Mulawarman } \\
\text { University of Queensland }\end{array}$ & $\begin{array}{l}\text { AD, Adg, RS, } \\
A F\end{array}$ \\
\hline Borneo Project in East Kalimantan & $\begin{array}{l}\text { East } \\
\text { Kalimantan }\end{array}$ & Global Green & AD, Adg, RS \\
\hline $\begin{array}{l}\text { FORCLIME - Berau Demonstration } \\
\text { Activity }\end{array}$ & $\begin{array}{l}\text { East } \\
\text { Kalimantan }\end{array}$ & $\begin{array}{l}\text { Kreditanstalt für Wiederaufbau } \\
\text { Gesellschaft für Internationale } \\
\text { Zusammenarbeit } \\
\text { Ministry of Forestry } \\
\text { District and provincial governments }\end{array}$ & $A D, A d g$ \\
\hline $\begin{array}{l}\text { FORCLIME - Malinau Demonstration } \\
\text { Activity }\end{array}$ & $\begin{array}{l}\text { East } \\
\text { Kalimantan }\end{array}$ & $\begin{array}{l}\text { Kreditanstalt für Wiederaufbau } \\
\text { Gesellschaft für Internationale } \\
\text { Zusammenarbeit } \\
\text { Ministry of Forestry } \\
\text { District and provincial governments }\end{array}$ & $A D, A d g$ \\
\hline Hutan Lestari untuk Orangutan & $\begin{array}{l}\text { East } \\
\text { Kalimantan }\end{array}$ & $\begin{array}{l}\text { PT. Restorasi Habitat Organgutan } \\
\text { Indonesia }\end{array}$ & $A D, A d g$ \\
\hline
\end{tabular}


Appendix 1. Continued

\begin{tabular}{|c|c|c|c|}
\hline Project name & Province & Organization & $\operatorname{Aims}^{\mathrm{a}}$ \\
\hline Kutai Barat, HKM: Heart of Borneo & $\begin{array}{l}\text { East } \\
\text { Kalimantan }\end{array}$ & World Wide Fund & $A D$ \\
\hline \multirow[t]{8}{*}{ Malinau Avoided Deforestation Project } & \multirow{8}{*}{$\begin{array}{l}\text { East } \\
\text { Kalimantan }\end{array}$} & PT Inhuntani II & \multirow[t]{8}{*}{$A D$} \\
\hline & & Malinau Regency & \\
\hline & & Kreditanstalt für Wiederaufbau & \\
\hline & & Fauna \& Flora International & \\
\hline & & $\begin{array}{l}\text { Gesellschaft für Internationale } \\
\text { Zusammenarbeit }\end{array}$ & \\
\hline & & Tropenbos International & \\
\hline & & Global EcoRescue & \\
\hline & & Borneo Tropical Rainforest Foundation & \\
\hline \multirow[t]{2}{*}{ Meru Betiri National Park } & \multirow[t]{2}{*}{ East Java } & $\begin{array}{l}\text { International Tropical Timber } \\
\text { Organization }\end{array}$ & \multirow[t]{2}{*}{ AD, Adg, RS } \\
\hline & & $\begin{array}{l}\text { Forest Research and Development } \\
\text { Agency }\end{array}$ & \\
\hline Gede-Salak REDD Project & West Java & Conservation International & RS \\
\hline \multirow{4}{*}{$\begin{array}{l}\text { TEBE Project (Towards enabling } \\
\text { mitigation of climate change through } \\
\text { promotion of community-based } \\
\text { economic growth) }\end{array}$} & \multirow{4}{*}{$\begin{array}{l}\text { East Nusa } \\
\text { Tenggara }\end{array}$} & KYEEMA Foundation & \multirow[t]{4}{*}{$A D$} \\
\hline & & AusAID & \\
\hline & & Yayasan Peduli Sanlima & \\
\hline & & Yayasan Timor Membangun & \\
\hline $\begin{array}{l}\text { Korea-Indonesia Joint Project for } \\
\text { Adaptation and Mitigation of Climate } \\
\text { Change in Forestry }\end{array}$ & $\begin{array}{l}\text { West Nusa } \\
\text { Tenggara }\end{array}$ & Korea International Cooperation Agency & $\begin{array}{l}A D, A d g, R S, \\
A F\end{array}$ \\
\hline \multirow{2}{*}{$\begin{array}{l}\text { Sustainable Management of Poigar } \\
\text { Forest }\end{array}$} & \multirow{2}{*}{$\begin{array}{l}\text { North } \\
\text { Sulawesi }\end{array}$} & ONF International & \multirow[t]{2}{*}{$A D, R S, A F$} \\
\hline & & Green Synergies & \\
\hline \multirow{2}{*}{$\begin{array}{l}\text { Gorontalo: Establishment \& } \\
\text { Management of Nantu National Park }\end{array}$} & \multirow[t]{2}{*}{ Gorontalo } & Gorontalo University & \multirow[t]{2}{*}{$A D$} \\
\hline & & Yayasan Adudu Nantu Internasional & \\
\hline Mamuju Habitat & West Sulawesi & PT Inhutani I & $\begin{array}{l}A D, A d g, R S, \\
A F\end{array}$ \\
\hline Jayapura Pilot Project & Papua & World Wide Fund & $A F, R S$ \\
\hline $\begin{array}{l}\text { Mamberamo River Basin Forest Carbon } \\
\text { Project }\end{array}$ & Papua & Conservation International & $\mathrm{N} / \mathrm{A}$ \\
\hline \multirow[t]{4}{*}{ Papua Avoided Deforestation Initiatives } & \multirow[t]{4}{*}{ Papua } & Sekala & \multirow[t]{4}{*}{$A D$} \\
\hline & & Papua Civil Society Support Foundation & \\
\hline & & World Resource Institute & \\
\hline & & Telapak & \\
\hline \multirow{2}{*}{$\begin{array}{l}\text { Papua REDD Project - Mamberamo and } \\
\text { Mimika }\end{array}$} & \multirow[t]{2}{*}{ Papua } & New Forests Asset Management & \multirow[t]{2}{*}{$A D$} \\
\hline & & PT Emerald Planet & \\
\hline
\end{tabular}

a AD: avoid deforestation, Adg: avoid degradation, RS: restoration, AF: afforestation.

Sources: REDD+ Indonesia (http://www.redd-indonesia.org/), UN-REDD+ Programme for Indonesia (Mardiastuti 2012a), REDD desk (www.theredddesk.org), IGES (http://redd-database.iges.or.jp/redd/) and CIFOR's Global Comparative Study on REDD+ (http://www. cifor.org/gcs/about-gcs/redd-project-sites/redd-project-sites-in-indonesia.html ). 


\section{Appendix 2. MRV strategies and implementation of REDD+ demonstration activities}

\begin{tabular}{|c|c|c|c|}
\hline Project name & Location & MRV strategy and implementation & Sources \\
\hline Ulu Masen Ecosystem & Aceh & $\begin{array}{l}\text { - Using Tier } 1 \text { method to estimate carbon } \\
\text { stocks, gradually moving to Tier } 2 \text { and } \\
\text { Tier } 3 \text {. }\end{array}$ & $\begin{array}{l}\text { Project design } \\
\text { document for Carbon, } \\
\text { Community and } \\
\text { Biodiversity Alliance } \\
\text { (CCBA) (Rafli et al. 2007) }\end{array}$ \\
\hline $\begin{array}{l}\text { Merang REDD+ Pilot } \\
\text { Project }\end{array}$ & South Sumatra & $\begin{array}{l}\text { - Carbon measurements by professionals, } \\
\text { with limited involvement of local } \\
\text { community. } \\
\text { - Carbon data may be integrated into the } \\
\text { provincial government's action plan on } \\
\text { climate change. }\end{array}$ & $\begin{array}{l}\text { - Merang REDD+ Pilot } \\
\text { Project summary } \\
\text { of results and } \\
\text { achievements (GIZ 2011) } \\
\text { - Interview }\end{array}$ \\
\hline $\begin{array}{l}\text { Community Forest } \\
\text { Ecosystem Services }\end{array}$ & $\begin{array}{l}\text { Jambi } \\
\text { West } \\
\text { Kalimantan }\end{array}$ & MRV strategy has not been specified. & $\begin{array}{l}\text { - Plan Vivo Project idea } \\
\text { note (FFI 2012) }\end{array}$ \\
\hline $\begin{array}{l}\text { Kalimantan Forest and } \\
\text { Climate Partnership }\end{array}$ & $\begin{array}{l}\text { Central } \\
\text { Kalimantan }\end{array}$ & $\begin{array}{l}\text { - Carbon measurements by professionals, } \\
\text { with limited involvement of local } \\
\text { community. } \\
\text { - Barriers for community involvement: } \\
\text { - Demanding technical requirements } \\
\text { - Low capacity and interest } \\
\text { - Data quality issues } \\
\text { - Carbon data will be used to calibrate the } \\
\text { Indonesian National Carbon Accounting } \\
\text { System (INCAS). }\end{array}$ & $\begin{array}{l}\text { - Project design } \\
\text { document (KFCP 2009) } \\
\text { - Interview }\end{array}$ \\
\hline $\begin{array}{l}\text { Rimba Raya Biodiversity } \\
\text { Reserve Project }\end{array}$ & $\begin{array}{l}\text { Central } \\
\text { Kalimantan }\end{array}$ & - Carbon measurements by professionals. & $\begin{array}{l}\text { Project design } \\
\text { document for VCS } \\
\text { (Bollick et al. 2011) }\end{array}$ \\
\hline $\begin{array}{l}\text { Rewetting Tropical } \\
\text { Peat Swamp Forest at } \\
\text { Sebangau National Park }\end{array}$ & $\begin{array}{l}\text { Central } \\
\text { Kalimantan }\end{array}$ & - Automatic measurement of water level. & $\begin{array}{l}\text { - Project design } \\
\text { document for CCBA } \\
\text { (WWF 2012) }\end{array}$ \\
\hline $\begin{array}{l}\text { Meru Betiri National } \\
\text { Park }\end{array}$ & East Java & $\begin{array}{l}\text { - Carbon measurements with some } \\
\text { involvement of local community. } \\
\text { - Carbon data may be integrated into the } \\
\text { provincial government's action plan on } \\
\text { climate change. }\end{array}$ & - Interview \\
\hline
\end{tabular}



CIFOR Working Papers contain preliminary or advance research results on tropical forest issues that need to be published in a timely manner to inform and promote discussion. This content has been internally reviewed but has not undergone external peer review.

We conducted a literature review of participatory monitoring and existing PMRV approaches to identify strategies and conditions that support the development and implementation of sustainable PMRV in the REDD+ context. To identify data and processes that should be included in PMRV, we reviewed MRV requirements in the REDD+ context. The literature is analyzed to summarize the lessons learned from participatory monitoring, examine when, where and how PMRV has been developed and implemented, and identify any knowledge gaps. With Indonesia as our case study, we explored the feasibility of PMRV implementation and assessed how PMRV could be integrated into the national MRV system. We examined the proposed national MRV system in Indonesia, compiled a database of REDD+ projects and conducted short interviews with selected project proponents. 